\title{
MULTIBEAM INVESTIGATION OF AN ARTIFICIAL REEF SETTLEMENT IN THE ADRIATIC SEA (ITALY) 33 YEARS AFTER ITS DEPLOYMENT**
}

\author{
Sarine Manoukian ${ }^{1,2, * *}$, Gianna Fabi ${ }^{l}$ and David F. Naar ${ }^{2}$ \\ ${ }^{1} \mathrm{CNR}$ - Istituto di Scienze Marine, Sede di Ancona \\ (Largo Fiera della Pesca, 60125 Ancona, Italy) \\ ${ }^{2}$ College of Marine Science, University of South Florida \\ (140 $7^{\text {th }}$ Ave South, St. Petersburg, 33701 FL, USA) \\ **Corresponding author: sarine.manoukian@an.ismar.cnr.it
}

\begin{abstract}
A B S T R A C T
Artificial reefs (ARs) are becoming a popular biological and management component in shallow water environments characterized by soft seabed, representing both important marine habitats and tools to manage coastal fisheries and resources. Because of the unstable nature of sediments, they require a detailed and systematic investigation that acoustic systems can provide. An AR into the marine environment acts as an open system with exchange of material and energy, altering the physical and biological characteristics of the surrounding area. The AR stability will depend on the balance of scour, settlement, and burial resulting from ocean conditions over time. The acoustic systems are efficient tools in monitoring the environmental evolution around ARs, whereas water turbidity can limit visual dive and ROV inspections. High-frequency multibeam echosounder offers the potential of detecting fine-scale distribution of reef units, providing an unprecedented level of resolution, coverage, and spatial definition. In 2008 the EM3002 multibeam was used to investigate the first scientifically-planned AR in Italy deployed during 1974-75. After 33 years the AR is almost in perfect condition. A considerable scouring around the structures and some vertical/horizontal movements of the single units have occurred. Moreover a deepening of the whole area hosting the AR was observed.
\end{abstract}

\section{RESUMO}

Os recifes artificiais (ARs) estão se tornando um componente biológico e de manejo de ambientes de áreas rasas com substratos característicos não rígidos, representando habitats marinhos importantes e ainda constituindo uma ferramenta para o manejo da pesca e dos recursos costeiros. Devido à natureza instável dos sedimentos, exigem um estudo detalhado e sistemático que os sistemas acústicos podem disponibilizar. Um RA atua no ambiente marinho como um sistema aberto com troca de materiais e energia, alterando as características físicas e biológicas das áreas que o cerca. A estabilidade do RA dependerá do equilíbrio entre a escavação, o assentamento e aterramento resultantes das ações do oceano no decorrer do tempo. Os sistemas acústicos são ferramentas eficientes no monitoramento da evolução ambiental ao redor dos ARs, uma vez que a turbidez da água pode limitar o mergulho visual e as inspeções ROV. A ecosonda multifeixe de alta frequência oferece meios para identificar com precisão a distribuição das unidades recifais, com nível de resolução, cobertura e definição especial. Em 2008, a sonda multifeixe EM3002 foi usada para estudar a primeira implantação cientificamente planejada de RA na Itália, durante 1974-75. Após 33 anos, o RA está praticamente em perfeitas condições. Foram observadas a ocorrência de escavação considerável ao redor das estruturas, alguns movimentos vertical/horizontal das unidades isoladas e ainda o aprofundamento de toda a area que abriga o RA.

Descriptors: Artificial reef, Multibeam, Acoustic image, Scouring, Deepening.

Descritores: Recifes artificiais, Multifeixes, Imagem acústica, Escavação, Aprofundamento.

\section{INTRODUCTION}

The marine environment worldwide is coming under increasing pressure from anthropogenic activities. With the collapse of many offshore fisheries, and increasing competition amongst industries for resources such as oil, gas, and marine

(*) Paper presented at the $9^{\text {th }}$ CARAH - International Conference on Artificial Reefs and Related Aquatic Habitats on 8-13 November, Curitiba, PR, Brazil. aggregates, there is a growing need for improved understanding of seafloor ecosystems to facilitate sustainable management of offshore resources. Human activities can cause a wide variety of impacts on the seabed environment. The need to identify and map different types of benthic habitats and associated biological communities to protect vulnerable, rare or ecologically important areas is now widely recognized (PICKRILL; TODD, 2003; BEAMAN; HARRIS, 2005). Since artificial reefs (ARs) have become a 
popular biological component in shallow water environments characterized by soft seabed, they represent important marine habitats. Because of the unstable nature of sediments, they require the detailed and systematic investigation that acoustic systems can provide. An AR is "one or more objects of natural or human origin deployed purposefully on the seafloor to influence physical, biological, or socioeconomic processes related to living marine resources" (SEAMAN; JENSEN, 2000). The main intent is to mimic some characteristics of the natural rocky environment. ARs range in structure and complexity from sunken ships to objects custom-made from a wide range of materials (GROVE et al., 1991; BROWN; HARPER, 2006). They have been deployed around the world for a wide number of reasons including fisheries protection and enhancement, environmental protection and rehabilitation, research, education, and tourism (HARRIS, 2006; OSPAR COMMISSION, 2009).

An AR within the marine environment acts as an open system with exchange of material and energy, altering the physical and biological characteristics of the area where it is deployed. ARs can modify flow velocity and turbulence intensity around and in the vicinity of the structures, which can lead to scouring and changes in sediment accumulation in the surrounding area (GROVE et al; 1991; FARMER et al., 1999; RAMBABU et al., 2002; YU; URA, 2002; RAMBABU et al., 2003; STAUBLE; TABAR, 2003; STAUBLE, 2003; INMAN; JENKINS, 2005; QUINN, 2006; JENKINS et al., 2007; MAYER et al., 2007; WOLFSON et al., 2007). The environmental changes on the adjacent seafloor can, in turn, physically affect the artificial structures. Thus the stability of ARs will depend on the balance of scour, settlement, and burial resulting from ocean conditions, over time (GROVE et al; 1991). Although much research has been conducted on terrain change and scour processes operating around anthropogenic structures in the near-shore (e.g. RAMBABU et al., 2002; YU; URA, 2002; RAMBABU et al., 2003; STAUBLE; TABAR, 2003; STAUBLE, 2003; QUINN, 2006; MAYER et al., 2007), only limited research has been conducted on horizontal movement, deepening and scouring of unique ecological systems such as ARs (SHYUE, 1998; FARMER et al., 1999; SHYUE; YANG, 2002; MANOUKIAN et al., 2004; BROWN; HARPER, 2006). Detailed quantitative information on seabed morphology and terrain changes around individual reef units have been obtained by SHYUE; YANG (2002), while BROWN; HARPER (2006) worked on an experimental AR particularly suited for scientific studies, offering a replicated reef design. But there is still a lack of long term monitoring of the AR systems and, further, of a detailed description of how the different typologies of ARs respond to environmental factors and their impact on the surrounding ecosystem.

Acoustic systems are efficient tools capable of monitoring the environmental (physical and biological) evolution around ARs, whereas visual dive and ROV inspections can be limited by water turbidity. However, techniques such as single beam echo sounder and side scan sonar have spatial limitations and navigation and towfish control difficulties. On the other hand, high-frequency multibeam echosounders offer the potential of detecting and defining the fine-scale distribution of reef units.

These high resolution systems are able to achieve 100\% coverage of seabed geology and geomorphology over relatively broad spatial scales, offering an unprecedented level of resolution, coverage, and spatial definition (KENNY et al., 2003; BERMAN et al., 2005). In recent years the application of acoustic-mapping methodology, in particular the use of acoustic ground-discrimination systems used in conjunction with ground-truth sampling, has become common practice in monitoring and mapping seabed habitats (NAAR et al., 1999; COCHRANE; LAFFERTY, 2002; FOSTER-SMITH et al., 2004; JORDAN et al., 2005; FREITAS et al., 2008). Because acoustic data are less able to detect changes in the biological components of the seabed, classifications of different seabed ecosystems tend to be driven largely by physical criteria (KOSTYLEV et al., 2001; FREITAS et al., 2003). There is no doubt that acoustic technologies have greatly improved the definition of physical aspects of seabed environments and provide unique insights into biological community composition and distribution. As regards seabed characterized by a high degree of sediment heterogeneity, our understanding of the community structure and spatial distributions of biological assemblages is strengthened through the combined use of acoustic data (specifically backscatter intensity imagery along with bathymetry), and point-source biological and sediment samples. When studying large areas of the seabed, biological sampling at high intensity is unlikely to be cost-effective, and if acoustic data are not collected at the same time, smallscale patchiness in the seabed environment will likely be missed. Given the benefits of acoustic systems for the study and characterization of the seabed, it is not surprising that acoustic data are used as the primary basis for classifying seabed environments, in terms of both physical and biological components (EASTWOOD et al., 2006).

In the present study an AR in the Western Adriatic Sea, Italy, was acoustically investigated 33 years after its deployment to assess its temporal evolution, investigating scour, burial, deepening, and any horizontal changes. Further, advanced multibeam 
echosounder technology integrated with postprocessing software was used in the study, permitting an appraisement of the efficiency and limitations of the acoustic system when used in AR mapping.

\section{Material and Methods}

The acoustic survey was carried out in June 2008 at the first scientifically-planned AR in Italy. The reef was deployed during 1974-75 about $5.5 \mathrm{~km}$ from the Porto Recanati shoreline, at 12-15 m depth, on a muddy seabed (Fig. 1). The AR was constructed on behalf of CNR-ISMAR of Ancona for the purpose of: a) preventing illegal trawling inside the $5.5 \mathrm{~km}$ coastal zone; b) inducing finfish re-population; c) enhancing biodiversity through the settlement of hard-bottom communities; d) redirecting the flow of excess nutrients occurring in Adriatic coastal waters into edible biomass through extensive cultures of filterfeeders such as mussels (Mytilus galloprovincialis) and oysters (Ostrea edulis and Crassostrea gigas), and e) enhancing small-scale fisheries. The reef has a central "oasis" ( 3 ha) composed of 12 pyramids (Fig. 2 ; in the present paper, Porto Recanati AR refers to the central oasis), each one built of 14 concrete cubic blocks $(2 \times 2 \times 2 \mathrm{~m})$. Each pyramid stands $6 \mathrm{~m}$ high. The pyramids were placed on gravel "mattresses" to spread the weight and prevent deepening, and were deployed in a rectangular arrangement, about $50 \mathrm{~m}$ apart. Stone piles were placed among the pyramids to make the reef system continuous and two old vessels were sunk at the centre of the oasis. The reef oasis is surrounded by a protected area (2,000 ha) extending from 3 to 6.5 $\mathrm{km}$ from the coast where the cubic blocks were dispersed. A total of 453 blocks were used: 168 for the construction of the pyramids and 285 as isolated anti- trawling blocks, giving a total volume of $3,624 \mathrm{~m}^{3}$. The gravel laid under the pyramids amounted to a volume of $396 \mathrm{~m}^{3}$. In all, more than $4,000 \mathrm{~m}^{3}$ of material was deployed.

A Kongsberg Simrad EM3002 bathymetric system mounted on the CNR-ISMAR (Ancona) R/V "Tecnopesca II" was used. The echosounder operated at a frequency of $300 \mathrm{kHz}$, fanning out up to 254 acoustic beams at a maximum ping rate of $40 \mathrm{~Hz}$ and an angle of $130^{\circ}$. This yielded swaths that were up to $\sim 4$ times the water depth. The position of the boat was determined by 24-hour differential global positioning system (DGPS) navigation connected to a geostationary satellite, while an Anshutz Standard 20 gyrocompass and a Seatex Motion Remote Unit 4.0 were used to compensate for ship heading and motion. With differential GPS, the system was capable of $\mathrm{cm}$ resolution with a depth accuracy of $5 \mathrm{~cm}$ RMS and a horizontal positioning accuracy of less than $1 \mathrm{~m}$. Angular misalignment between transducer, motion sensor and gyrocompass, together with latency, was calibrated by a patch test at sea. Sound speed profile measurements were made by Smart SV \& Pressure 4609 of Applied Micro-system Ltd. The data were logged using SIS software, and subsequently postprocessed using CARIS software. Tidal corrections were applied to the depth soundings by using verified downloaded tide data available for the study area from www.mareografico.it. Digital Terrain Models and finally 3D images were obtained.

The vessel's speed was maintained at around 3 knots and the distance between each parallel survey line was established in such a way as to obtain at least $20 \%$ of overlapping, thus guaranteeing more than $100 \%$ coverage.

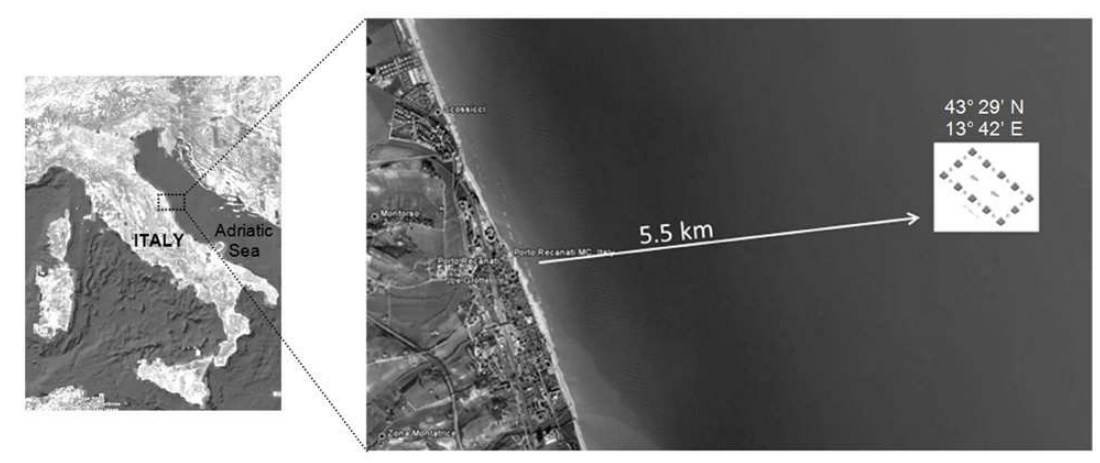

Fig. 1. Study area location showing the position of Porto Recanati artificial reef (Google Earth images). 


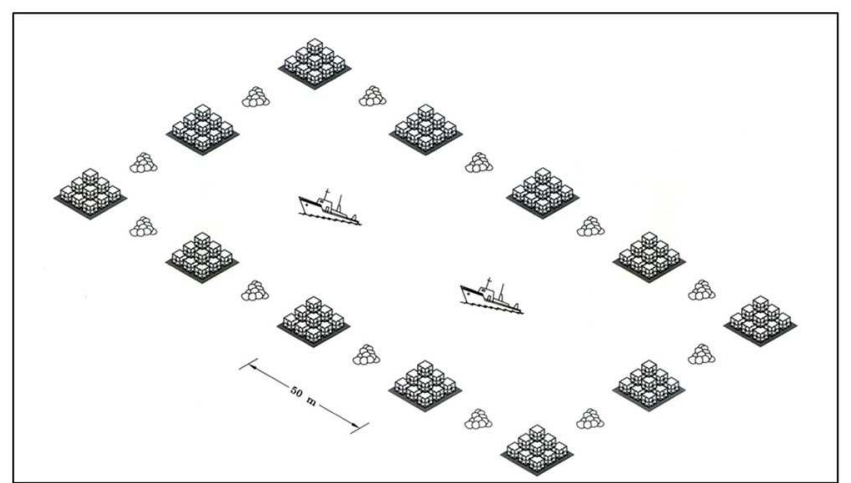

Fig. 2. Plan of the central oasis of Porto Recanati artificial reef (not to scale).

\section{RESULTS}

The grey-scale shaded relief image of the central oasis of Porto Recanati AR presented a mean depth of $15 \mathrm{~m}$ and the high-resolution data were capable of distinguishing between the different reef modules such as the 12 3-layer pyramids, the stone piles and the surface shape of one of the two wrecks
(Fig. 3). The rectangular arrangement was correctly constructed(?) and is still well preserved, while the stone piles had been displaced to the central part of the oasis instead of being between each pyramid.

The high-quality multibeam data also revealed that most of the 12 pyramids are still entire (Fig. 4), with every single one of the $2 \times 2 \times 2 \mathrm{~m}$ cubes clearly outlined.

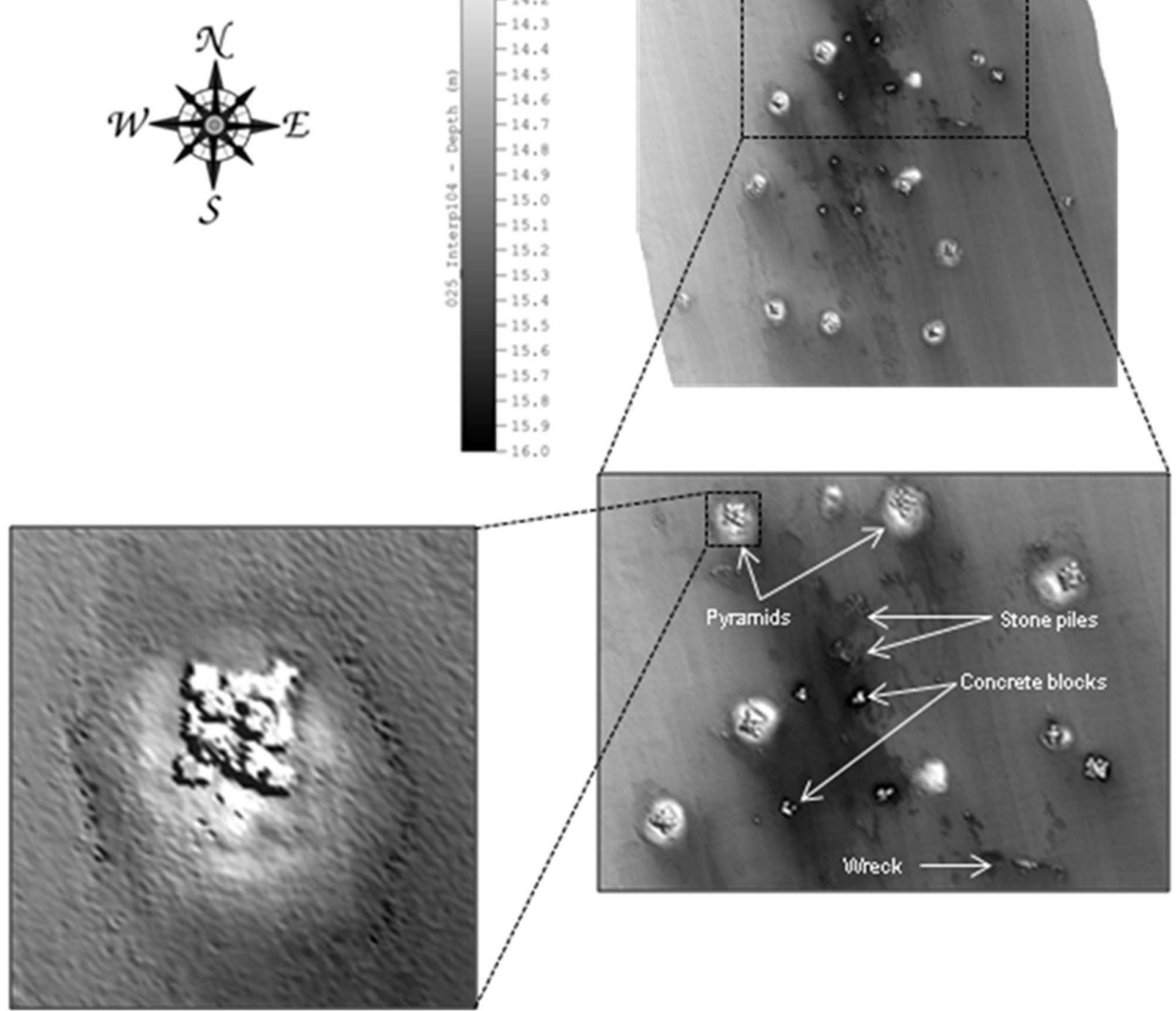

Fig. 3. Grey-scale detailed bathymetric data from MBES EM3002 of Porto Recanati artificial reef. 

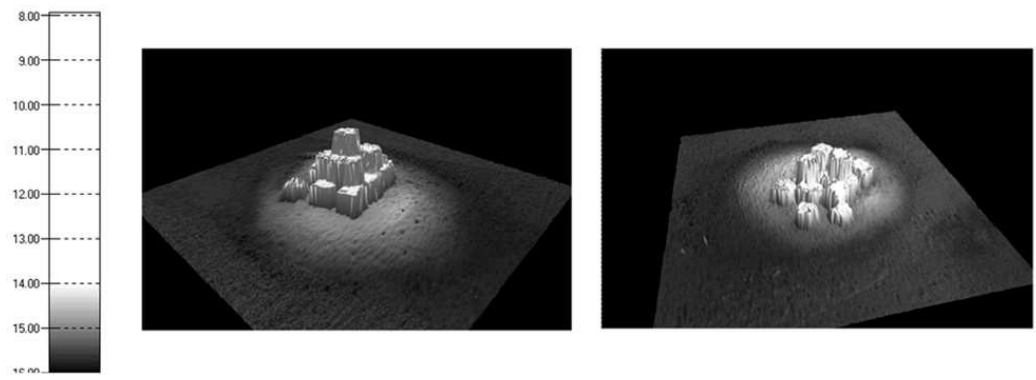

Fig. 4. High-resolution 3-D images from MBES EM3002 of an integral (left) and notintegral (right) 3-layers pyramids.

White circular areas defined by darker contours were observed around the pyramids (Figs. 3 and 4) and indicate an accumulation of sediment due to scouring. This geological process is well represented by black areas extending southeastwards from the structures in the NW-SE direction of the local currents parallel to the shoreline. Figure 5 shows a depth profile traversing a complete pyramid. The sediment pile with a height of approximately $1 \mathrm{~m}$ is clearly identified together with the scouring erosion tracks. The pyramid presents its full height of $6 \mathrm{~m}$.

Scouring was also observed around smaller units such as the groups of 3 concrete blocks (Fig. 6). Again, the extended NW-SE shapes of the darker areas lay in the same direction as the current, with much more pronounced (much darker) scouring on the NW side of the units and more prolonged towards the SE.

A second depth profile (Fig. 7) passing through an area free of any kind of structures within the oasis, indicates a certain amount of deepening undergone by both the whole area hosting the reef and the under-current area in the southeasterly direction. A depth difference of about $1 \mathrm{~m}$ was found between the seabed where the AR is situated and the surrounding area.

Of the two ships deliberately sunk during the reef deployment, the shape of one of them was hardly detectable because it had almost completely subsided (Fig. 8).

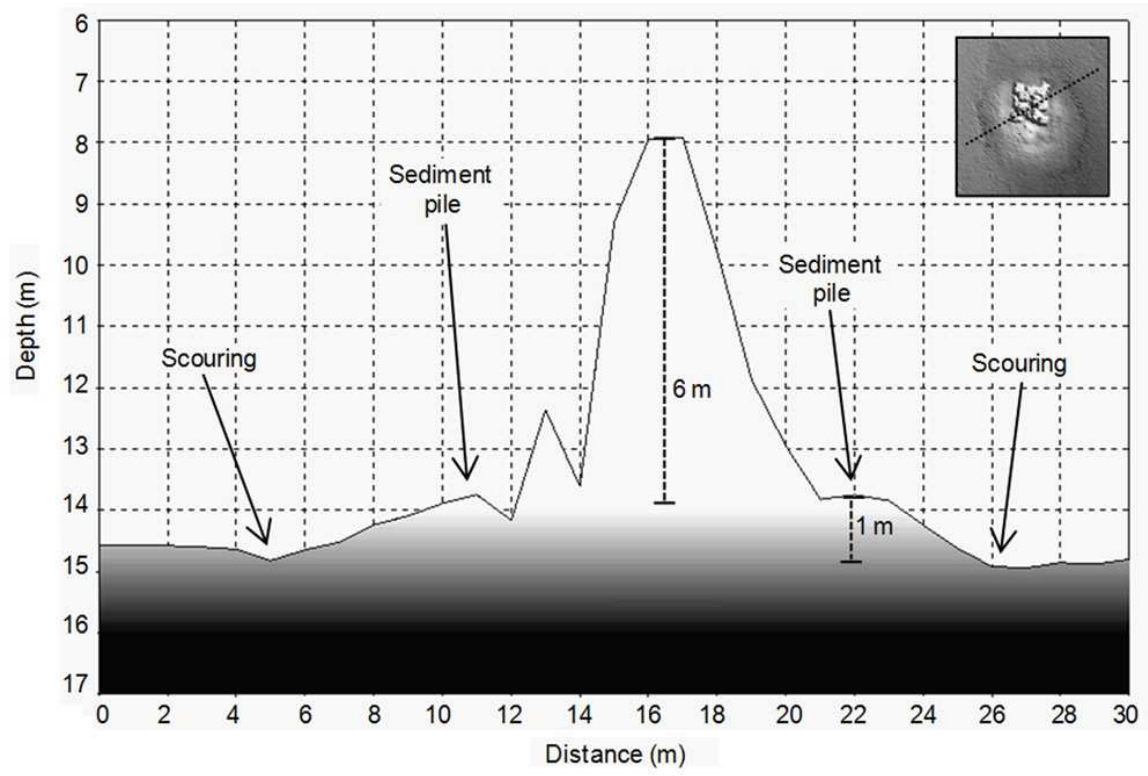

Fig. 5. Depth profile across an integral pyramid. 


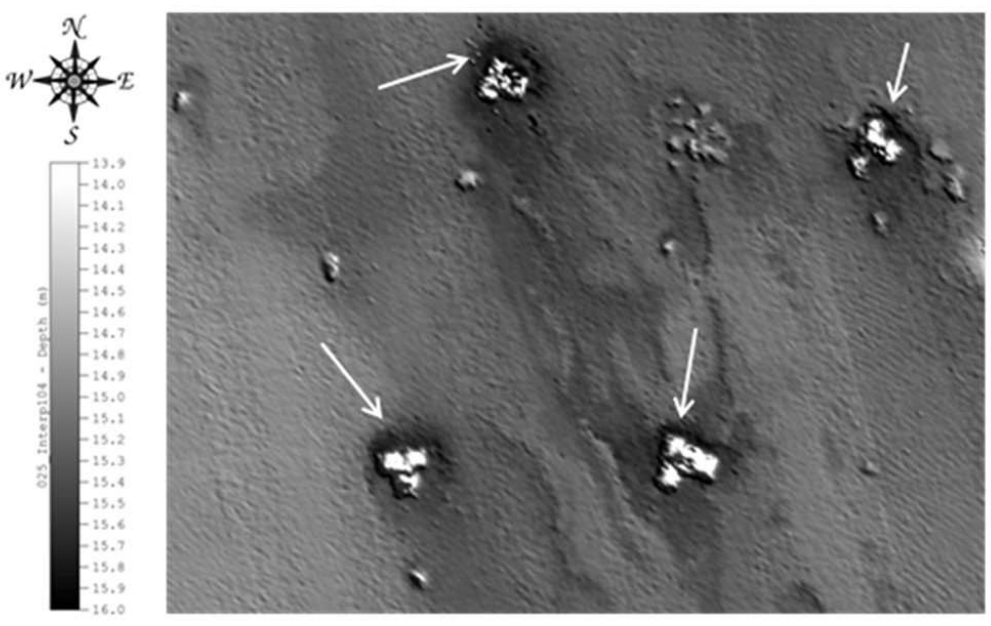

Fig. 6. Grey-scale MBES EM3002 image of a particular region of Porto Recanati artificial reef. The white arrows show scour processes around small units of 3 concrete blocks each.

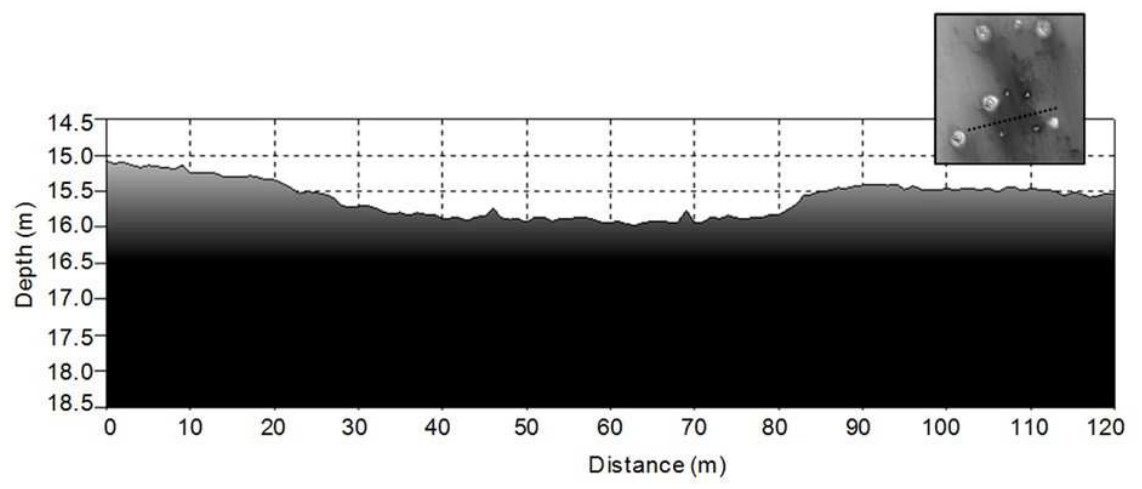

Fig. 7. Depth profile across the Porto Recanati artificial reef.

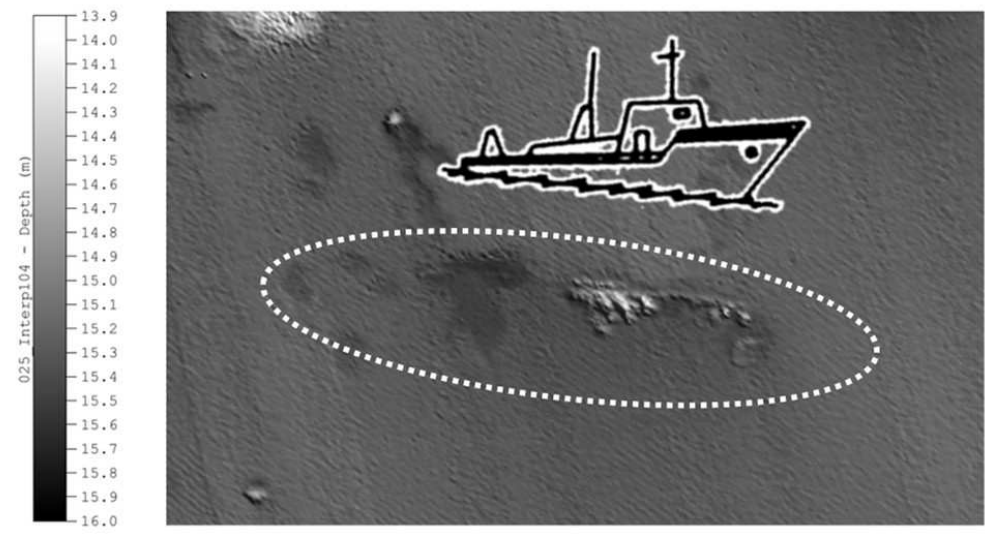

Fig. 8. Grey-scale MBES EM3002 image of the particular region of Porto Recanati artificial reef where the shape of one of the shipwreck was detected. 


\section{DisCUSSION}

Apart from the ecological role played by ARs in the marine environment, the lack of investigation into their post-deployment settlement has been commented on during the past two decades (SHYUE, 1998; SHYUE; YANG, 2002; BROWN; HARPER, 2006). The establishment of an AR on the seafloor induces a change in the local hydrodynamics increasing the flow velocity and the turbulence intensity. Due to the unstable nature of the sediments, many ARs may undergo diverse geophysical processes such as scouring, deepening, sinking, and destabilisation of the artificial structures on a wide range of temporal scales with a consequent reduction of the reef's key role in attracting finfish and other living organisms. The spatial extent of the scouring depends on the interaction between the geometrical/physical characteristics of the artificial units (e.g. lie, shape, size) and the marine environmental factors such as the seafloor morphology, the underlying geology, the water depth, the wave turbulence and the bottom currents, etc. Biological and chemical processes can also affect scouring. Moreover, some reef units may be partially or totally covered by sand and never relocated. Monitoring the spatial distribution of reef units and understanding the mechanisms of scouring, deepening, horizontal movements, and sand transportation involved on the local scale of an AR, could provide a reference for future site selection criteria, as previously mentioned by Shyue (1998).

Scouring, as the erosional and accretionary bedform pattern that occurs near objects that are on or near a sediment bed (INMAN; JENKINS, 2005), and the consequent burial of objects in response to forcing by waves and currents have been widely studied (e.g. FARMER et al., 1999; RAMBABU et al., 2002; YU; URA, 2002; RAMBABU et al., 2003; STAUBLE; TABAR, 2003; STAUBLE, 2003; INMAN; JENKINS, 2005; QUINN, 2006; JENKINS et al., 2007; WOLFSON et al., 2007; MAYER et al., 2007). Different techniques ranging from SCUBA diving observations, AUV and ROV inspections and acoustic surveys to numerical models have been developed and applied to investigate scouring initiated by the intentional (e.g. submerged breakwaters; vertical piles; submarine pipelines; etc.; RAMBABU et al., 2002; VIJAYA KUMAR et al., 2003; RAMBABU et al., 2003; STAUBLE; TABAR, 2003; STAUBLE, 2003) or accidental (e.g. mines, wrecks, etc.; HATTON et al., 2004; INMAN; JENKINS, 2005; QUINN, 2006; JENKINS et al., 2007; WOLFSON et al., 2007; MAYER et al., 2007) placing of an object on the seafloor.

However, only limited research has been conducted into horizontal movement, deepening and scouring of unique ecological systems such as ARs (FARMER et al., 1999; SHYUE, 1998; SHYUE; YANG, 2002; MANOUKIAN et al., 2004; BROWN; HARPER, 2006; SALA et al., 2007). As remarked by Shyue (1998), acoustic systems are efficient tools able to monitor the geo-morphological and geo-physical evolution of an AR, the settlement and scouring of which may be very difficult for divers or ROV to inspect due to time-cost effectiveness for the former, remote control difficulties for the latter, and water turbidity for both methodologies. Similarly, even an acoustic technology such as side scan sonar has navigation and towfish control difficulties in shallow water. Nevertheless, a single beam echosounder presents spatial limitations for sounding. A highresolution multibeam echosounder, on the other hand, provides a detailed picture of the distribution of changes in depth, sediment type, and bedforms in the area hosting an AR (FARMER et al., 1999; SHYUE, 1998; SHYUE; YANG, 2002; MANOUKIAN et al., 2004; BROWN; HARPER, 2006; SALA et al., 2007).

The results presented in this paper suggest that MBES EM3002 is able to clearly locate and even identify individual reef modules, their condition and any terrain change which has occurred around them. The resolution of the MBES together with the 3-D visualization technique provide realistic looking images of not only the single reef modules but even of the individual reef units such as each single $2 \times 2 \times 2 \mathrm{~m}$ concrete block. Thirty-three years later, the central oasis of Porto Recanati AR appears to be in very good condition, with the planned rectangular arrangement maintained and most pyramids still entire. The scour process is clearly evidenced around the artificial structures suggesting the presence of strong descending currents that have eroded the seabed, raising each pyramid on a sediment pile (of $1 \mathrm{~m}$ height). The direction of the scouring around the reef structures is the same as that of the main NW-SE current. The detail and coverage provided by the MBES offered useful approaches to the measurement of the degree of scour and/or burial of the structures, such as the construction of a profile across the seafloor surrounding the reef units.

In addition, the results show the outline of only one of the two sunken ships, implying that the second vessel had probably totally subsided and that the MBES was, therefore, unable to detect it.

This is the first study ever to have enabled us to obtain a complete view/map of the reef, recording the exact position of each artificial unit in respect to the others. For example, it revealed that the stone piles had been placed in the central part of the oasis instead of between the concrete pyramids as had been planned before the deployment. Moreover, this large-scale view of the area has provided useful information on the changes induced by the reef in the surrounding 
terrain. By contrast, before the advent of MBES technology, diving inspections had only been able to characterize single units without permitting any overall view of the reef system.

\section{ACKNOWLEDGEMENTS}

The authors wish to thank Gaz de France who supported the geo-physical survey financially, and the crew of the R/V Tecnopesca II for their help in data acquisition.

\section{REFERENCES}

BEAMAN, R. J.; HARRIS, P. T. Bioregionalization of the George V Shelf, East Antarctica. Cont. Shelf Res., v. 25, p. 1657 - 1691, 2005.

BERMAN, G.; NAAR, D. F.; HINE, A. C.; BROOKS, G.; TEBBENS, S. F.; DONAHUE, B. T.; WILSON, R. Geologic structure and hydrodynamics of Egmont Channel: An anomalous inlet at the mouth of Tampa Bay, Florida. J. coast. Res., v. 21, n. 2, p. 331 - 357, 2005

BROWN, C. J.; HARPER, C. Application of multibeam: mapping and monitoring of the Loch Linnhe artificial reef complex. Sea Technol., v. 47, n. 6, p. 31 - 36, 2006.

COCHRANE, G. R.; LAFFERTY, K.D. Use of acoustic classification of side scan sonar data for mapping benthic habitat in the Northern Channel Islands, California. Continent. Shelf Res., v. 22, p. 683 - 690, 2002.

EASTWOOD, P. D.; SOUISSI, S.; ROGERS, S. I.; COGGAN, R. A.; BROWN, C. J. Mapping seabed assemblages using comparative top-down and bottom-up classification approaches. Can. J. Fish. aquat. Sci., v. 63 , p. $1536-1548,2006$.

FARMER, A.; PALMSTEN, M.; NAAR, D. F. EM 3000 multibeam coastal surveys of hard bottom ledges and an artificial reef system west of Tampa Bay, Florida, Eos Trans. AGU, v. 80, n. 46, p. 520 - 521, 1999.

FOSTER-SMITH, R. L.; BROWN, C. J.; MEADOWS, W. J.; WHITE, W. H.; LIMPENNY, D. S. Mapping seabed biotopes at two spatial scales in the eastern English Channel. J. mar. biol. Ass. U.K., v. 84, p. 489 - 500, 2004.

FREITAS, R.; RODRIGUES, A. M.; QUINTINO, V. Benthic biotopes remote sensing using acoustics. J. expl mar. Biol. Ecol., v. 285 - 286, p. 339 - 353, 2003.

FREITAS, R.; RODRIGUES, A. M.; MORRIS, E.; PEREZLLORENS, J. L.; QUINTINO, V. Single-beam acoustic ground discrimination of shallow water habitats: $50 \mathrm{kHz}$ or $200 \mathrm{kHz}$ frequency survey? Estuar. coast. Shelf Sci., v. 78, p. $613-622,2008$.

GROVE, R. S.; SONU, C. J.; NAKAMURA, M. Design and engineering of manufactured habitats for fisheries enhancement. In: SEAMAN, W. JR; SPRAGUE, L.M. (Ed.). Artificial habitats for marine and freshwater fisheries. San Diego: Academic Press, 1991. p. 109 . 152.

HARRIS, L. E. Artificial reefs for ecosystem restoration and coastal erosion protection with aquaculture and recreational amenities. AQUIFER STORAGE
RECOVERY CONFERENCE, 6., 2006, Orlando. Proceedings...2006. p. $1-12$.

HATTON, K. A.; SMITH, H. D.; FOSTER, D. L. The scour and burial of submerged mines, Eos Trans. AGU, v. 84, n. 52 , p. $18-19,2004$.

INMAN, D. L.; JENKINS, S. A. Scour and burial of objects in shallow water. In: SCHWARTZ, M. (Ed.). Encyclopedia of coastal science. Dordrecht: SpringerVerlag, 2005. p. 825 - 830.

JENKINS, S. A.; INMAN, D. L.; RICHARDSON, M. D.; WEVER, T. F.; WASYL J. Scour and burial mechanics of objects in the nearshore. IEEE JI Ocean. Engng, v. 32, n. 1, p. 78 - 90, 2007.

JORDAN, A.; LAWLER, M.; HALLEY, V.; BARRETT, N. Seabed habitat mapping in the Kent Group of islands and its role in marine protected area planning. Aquat. Conserv., v. 15, p. 51 - 70, 2005.

KENNY, A. J.; CATO, I.; DESPREZ, M.; FADER, G.; SCHUTTENHELM, R. T. E.; SIDE, J. An overview of seabed-mapping technologies in the context of marine habitat classification. ICES J. mar. Sci., v. 60, p. 411 418, 2003.

KOSTYLEV, V. E.; TODD, B. J.; GORDON, B. J.; FADER, G. B. J.; COURTNEY, R. C.; CAMERON, G. D. M.; PICKRILL, R. A. Benthic habitat mapping on the Scotian Shelf based on multibeam bathymetry, surficial geology and sea floor photographs. Mar. Ecol. Prog. Ser., v. 219, p. 121 - 137, 2001.

MANOUKIAN, S.; FABI, G.; SPAGNOLO, A. Use of multibeam echosounder to detect terrain changes around two artificial reefs (Western Adriatic sea, Italy). COMMISSION INTERNATIONAL POUR L'ETUDE SCIENTIFIQUE DE LA MER MEDITERRANEE CONGRESS, 37., 2004, Barcelona. Proceedings... v. 37. 2004. p. 52.

MAYER, L. A.; RAYMOND, R.; GLANG, G.; RICHARDSON, M. D.; TRAYKOVSKI, P.; TREMBANIS, A. C. High-Resolution Mapping of Mines and Ripples at the Martha's Vineyard Coastal Observatory. IEEE Jl. Ocean. Engng, v. 32, n. 1, p. 133 - 149, 2007.

NAAR, D. F.; BERMAN, G.; DONAHUE, B.; DEWITT, N.; FARMER, A.; JARRETT, B.; PALMSTEN, M.; REYNOLDS, B. J.; WILDER, D. Preliminary Results from a EM 3000 multibeam class survey along the west coast of the Florida carbonate platform. Eos Trans. AGU, v. 80, n. 46, p. 519 - 520, 1999.

OSPAR COMMISSION. Assessment of construction or placement of artificial reefs. London: 2009. Biodiversity Series, publ. no. 438/2009. 27 p.

PICKRILL, R. A.; TODD B. J. The multiple roles of acoustic mapping in integrated ocean management, Canadian Atlantic continental margin. Ocean coast. Mgmt, v. 46, p. $601-614,2003$

QUINN, R. The role of scour in shipwreck site formation processes and the preservation of wreck-associated scour signatures in the sedimentary. J. Arch. Sci., v. 33, n. 10, p. 1419 - 1432, 2006.

RAMBABU, M.; NARASIMHA RAO, S.; SUNDAR, V. A simplified instrumentation for measuring scour in silty clay around a vertical pile. Appl. Ocean Res., v. 24, p. 355 - 360, 2002. 
RAMBABU, M.; NARASIMHA RAO, S; SUNDAR, V. Current-induced scour around a vertical pile in cohesive soil. Ocean Engng, v. 30, p. 893 - 920; 2003.

SALA, A.; FABI, G.; MANOUKIAN, S. Multibeam sonar for mapping and stationary hydroacoustic system for monitoring changes in fish biomass at an artificial reef (Northern Adriatic Sea). Sci. Mar., v. 71, n. 2, p. 347 $354,2007$.

SEAMAN, W. Jr.; JENSEN, A. C. Purposes and practices of artificial reef evaluation. In: SEAMAN, W. JR (Ed.). Artificial reef evaluation. New York: CRC Press, 2000. p. $1-19$.

SHYUE, S-W. Preliminary study on the distribution of artificial reefs by using multibeam echo sounder. OCEANS '98 IEEE/OES CONFERENCE, 1998, Nice. Proceedings ...1998. p. $1144-1148$.

SHYUE, S-W.; YANG, K-C. Investigating terrain changes around artificial reefs by using a multi-beam echosounder. ICES J. mar. Sci., v. 59, p. 338 - 342, 2002.

STAUBLE, D. K. The use of shoreline change mapping in coastal engineering project assessment. J. coast. Res., v. 38 , p. $178-206,2003$

STAUBLE, D. K.; TABAR, J. R. The Use of Submerged Narrow-Crested Breakwaters for Shoreline Erosion Control. J. coast. Res., v. 19, p. 684 - 722, 2003.
VIJAYA KUMAR, A.; NEELAMANI, S.; NARASIMHA RAO, S. Wave pressure and uplift forces on and scour around submarine pipeline in clayey soil. Ocean Engng, v. 30, p. $271-295,2003$.

WOLFSON, M. L.; NAAR, D. F.; HOWD, P. A.; LOCKER, S. D.; DONAHUE, B. T.; FRIEDRICHS, C. T.; TREMBANIS, A. C.; RICHARDSON, M. D.; WEVER, T. F. Multibeam observations of mine burial near Clearwater, Florida, including comparisons to predictions of wave-induced burial. IEEE JI Oceanic Engng, v. 32, n. 1, p. 103 - 118, 2007.

YU, S-C.; URA, T. Visual inspection of underwater structures by autonomous underwater vehicles based on positioning using artificial objects placed on them. ISOPE PACIFIC/ASIA OFFSHORE MECHANICS SYMPOSIUM, 5., 2002, Daejeon. Proceedings ..., 2002. p. $49-56$.

(Manuscript received 19 October 2010; revised 14 February 2011; accepted 15 June 2011) 